\title{
MATERIALS
}

\section{Identification of Common Millet from the Toyosato Site in Hokkaido by Means of a Scanning Electron Microscope}

\author{
Akiko MATSUTANI \\ Department of Anthropology and Prehistory, University Museum, \\ The University of Tokyo
}

\begin{abstract}
Among the three types of millet, "awa", "hie" and "kibi", which were cultivated in ancient Japan, the common millet, "kibi" (Panicum miliaceum L.), was less popular. Hence the samples of "kibi" reported from the archaeological sites were fewer than the other two types. As noted in the previous reports (MATSUTANI 1986b, 1987) grains of these millets are so small that their identification is often difficult, especially when carbonized, unless their cell structures are observed with a scanning electron microscope (SEM). So the carbonized grains of these millets might often be identified as "awa", which was the most popular one. The present study reports the discrimination of common millet among the carbonized grains from a site in Hokkaido belonging to the Satsumon period (9c.-12 c.) using SEM. Formerly, these grains were considered as "awa" (Setaria italica (L.) Beauw.).
\end{abstract}

Keywords Millet, Identification, SEM

\section{Introduction}

In contrast to abundant evidence of rice cultivation in Japanese prehistory, that of millet cultivation is very rare. In ancient Japan three types of millet were cultivated, namely "awa", "hie", and "kibi". They are matched to Setaria italica (L.) Beauv., Echinochloa utilis Ohwi et Yabuno, and Panicum miliaceum L. respectively. The ancestor of "kibi" is not known unlike the other two millets and the place where cultivated "kibi" originated is not clear yet.

This crop appears to have been less widely cultivated than the other two millets and its findings are also reported fewer than the others (Watanabe, 1970). Perhaps owing to their small grains, identification of these millets is often difficult and they are confused with each other or all

Article No. 3709 Received April 27, 1987

This study was supported by Grant No. 57107008 for scientific research from the Japanese Ministry of Education, Science and Culture. 
identified as "awa", which was the most common of the three. The present author has been interested in the discrimination of millets using spodography and scanning electron microscopy. In the previous two reports (MATSUTANI, 1986b, 1987) it was described and shown in photomicrographs how "awa" or "hie" was distinguished from other millets based on its characteristic cell patterns of lemma and palea. In this report carbonized grains identified as "kibi" are analysed.

The characters of "kibi" (common millet) are observed from the paleas of recent materials and compared with those of the excavated ones.

\section{Key for the Discrimination of Common Millet}

As in the case of "awa" and "hie", the epidermes of paleas and lemmas of "kibi" are constituted solely of the long cells, and the identification keys must be looked for in the features of these long cells, which have sinuate contours like those of the other two millets.

Firstly, as in "hie" (Matsutani, 1987) long cells of "kibi" do not have any tubercles at the end of cells. In this respect the long cells of "hie" or "kibi" are clearly distinguishable from those of "awa" which have clear tubercles (MATSUTANI 1986). However, in some varieties of "awa", such as "uruchi" (Fig. 11), tubercles are not observed in the long cells of palea and lemma (also reported in spodography by WATANABE, 1970). In such case the shape of the arms or the sinuated lateral parts of the long cells may be useful for the discrimination of "awa" from "kibi" or "hie". In "awa" the tips of the arms are club-shaped or widened (Fig. 12) while the tips of the arms in "kibi" or in "hie" are acute or narrowed and not club-shaped (Fig. 9).

Secondly, the length of the long cells of palea in "kibi" is longer than the breadth, and the standard ratio reaches to about double, which is quite different from the case in "hie" or in "awa", where the length of the long cells of palea is equal to or shorter than the breadth. In the previous report, the cell patterns under the surface of palea of "hie" were shown to be sharply dentated (Matsutani, 1987). In "kibi" also the cell patterns under the surface of palea are dentated (Fig. 10), but the above mentioned ratio of the long cells can be applied to the distinction between them.

Fig. 1. An isolated carbonized lump from the Toyosato Site.

Fig. 2. Magnification of Fig. 1 where the sinuate long cells were observed.

Fig. 3. Magnification of Fig. 2. Characteristic cell patterns of "kibi" were observed.

Fig. 4. An isolated grain with better outward form.

Fig. 5. Remains of cells under the surface perhaps derived from the neighboring grain.

Fig. 6. Magnification of Fig. 5 (90 degrees rotated).

Fig. 7. Ventral side view of a recent "kibi" with palea and lemma.

Fig. 8. Magnification of Fig. 7. Sinuate cell patterns of long cells are shown.

Fig. 9. Magnification of Fig. 8.

Fig. 10. Cell patterns under the surface of recent "kibi".

Fig. 11. Ventral side view of a variety of "awa" (Uruchi) in which no papillae or tubercles are found.

Fig. 12. Magnification of Fig. 11. Tip of the arm is club-shaped or widened rather than acute or narrowed. 


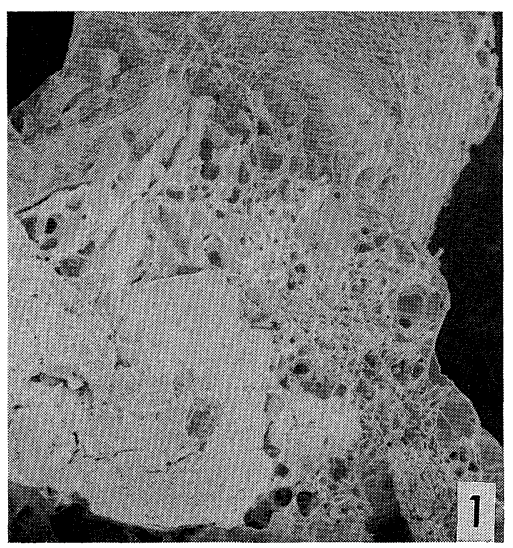

$500 \mathrm{u}$

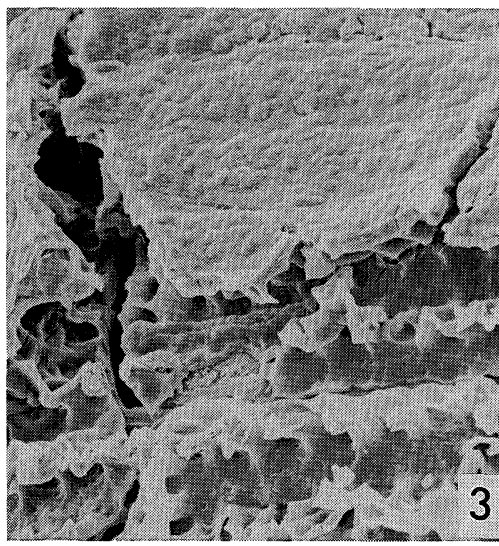

$50 \mathrm{u}$

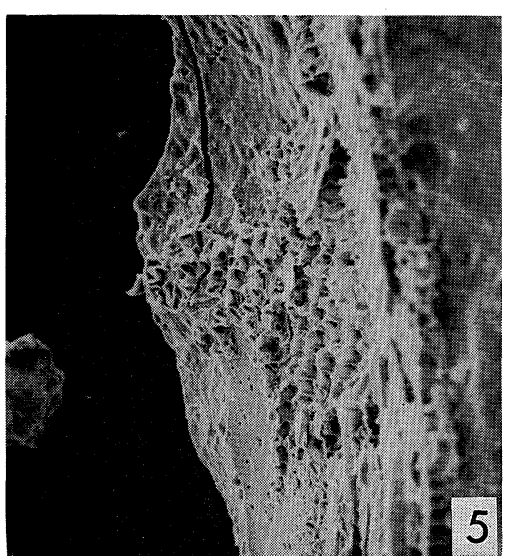

$50 \mathrm{u}$

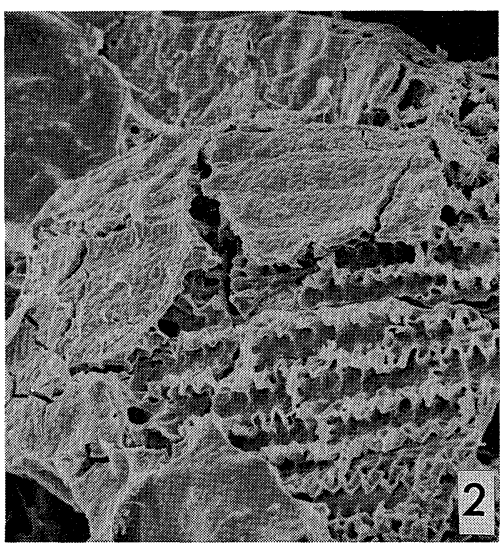

$50 \mathrm{u}$

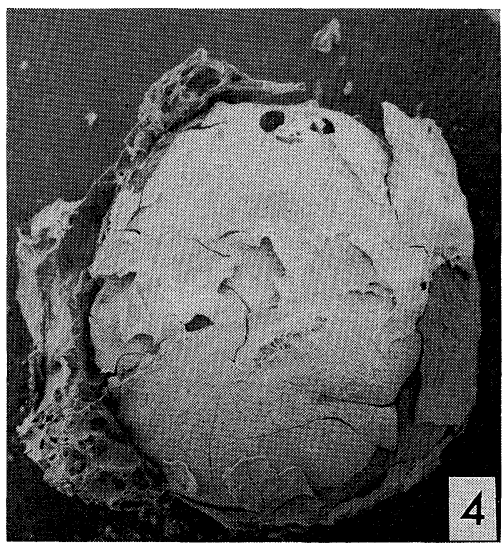

$500 \mathrm{u}$

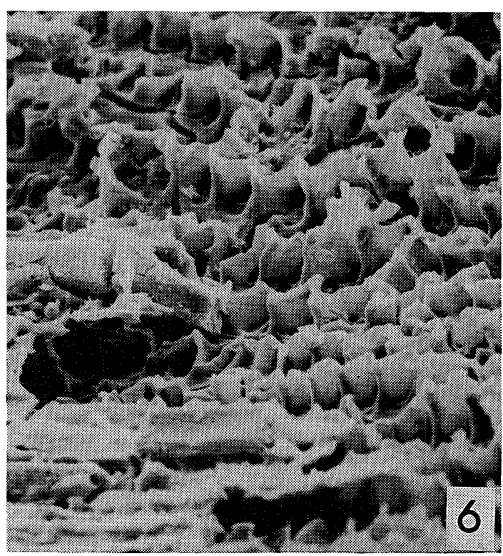

$50 \mathrm{u}$ 

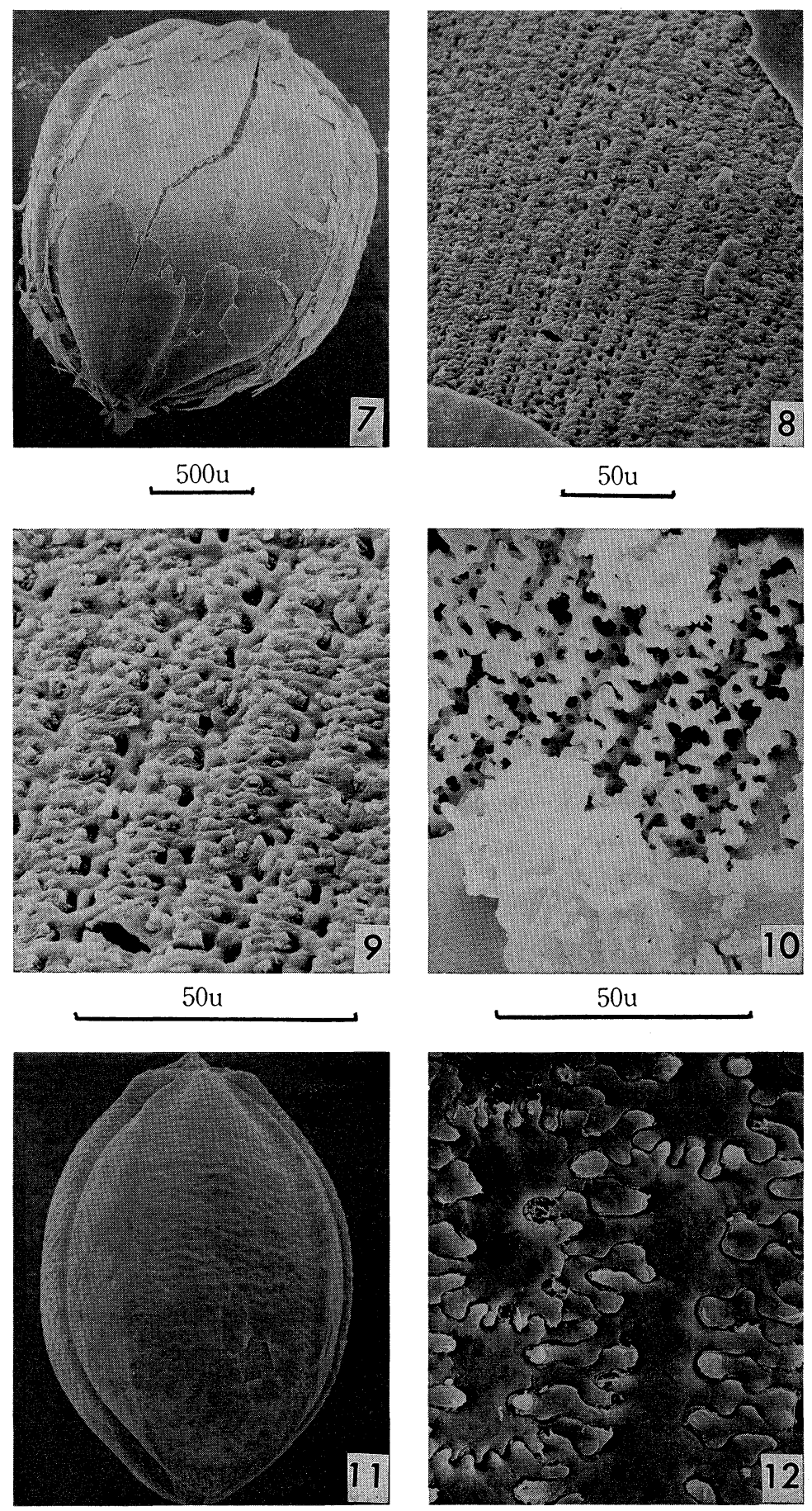

$500 u$

$50 \mathrm{u}$ 


\section{Materials}

Carbonized grains from the Toyosato Site at Toyotomi-cho in Hokkaido belonging to the Satsumon period $(9-12 \mathrm{c}$.), which is approximately parallell in age to the Heian period in mainland of Japan, were observed.

The site was excavated in 1958 and finds of carbonized grains of "awa" (Setaria italica) accompanied by "ryokuto" (Vigna radiata (L.) Wilczek) and "soba" (Fagopyrum esculentum Moench.), were reported without a detailed description or explanation of the identification (KoHNO, 1959). However, this identification was often cited as evidence of the cultivation of "awa" in the Satsumon period (HAYASHI, 1969). The present author had doubts that they were really "awa" and wanted to ascertain the kind of millet, for the author had experienced the detection of "kibi" from another Satsumon site (MatsuTANI, 1980). These grains had been preserved in Asahikawa City Museum without further examination until this study.

\section{Method}

The sample was composed of carbonized grains which were around $2 \mathrm{~mm}$ in diameter and fused into lumps. Some grains were isolated and were observed under a binocular microscope and two specimens with floral bracts such as lemma and/or palea were selected from among them. They were rinsed with acetone and mounted on stubs with double coated Nichiban tape. After being sputter-coated with platinum they were observed with a Hitachi S-700 SEM and photographed using both TriX film and Polaroid P665 film.

As in the case of "hie" (Matsutani, 1987), the recent samples for comparison were treated with the following operations. Namely, the uncarbonized kernel with palea and lemma was soaked in a dilute solution of hydrosulphate in a water bath for one hour. After being washed with distilled water three times and rinsed with acetone, they were then mounted and sputter-coated with platinum, then observed and photographed as in the case of excavated ones. Further, to see the cell structures under the surface, recent grains were incinerated with a plasma inorganizer (UMEMOTO and HozUmi, 1971) and were treated with dilute hydrochloric acid; the same procedures as above were then followed.

\section{Results}

The first specimen looked like a grain with a binocular, but with SEM several fragments of grains were observed to fuse into a lump and among them a part of the epidermis of palea or lemma was detected (Fig. 1) and when it was enlarged it revealed the characteristic long cells of sinuate contours without tubercles and under the surface dentated zigzag patterns of the structures (Fig. 2, 3). Length of the long cells was clearly longer than the breadth, and that was matched with the characteristics of long cells of palea or lemma of "kibi". The second specimen with a clearer outward form (Fig. 4) was also observed, but long cells of palea or lemma were not detected on the surface of this sample. Instead, the remains of cell patterns perhaps derived from the neighbouring grain were observed, and they also indicated the cell patterns characteristic of "kibi" (Figs. 5, 6). Scanning electron photomicrographs of recent "kibi" are shown in Figs. 7-10 for comparison. 


\section{Conclusions}

Based on the cell patterns of characteristic long cells and also on the cell patterns under the surface, carbonized grains uncovered from the Toyosato Site more than twenty years ago could be identified as "kibi" and not as "awa" as hitherto have been considered.

\section{Acknowledgements}

The author wishes to express her gratitude to Mr. Nobukatsu AoyAgI of the Museum of Asahikawa City who provided the carbonized millets from the Toyosato Site. The author also wishes to thank Emeritus Professor Naotune WatANABE, Department of Anthropology, Faculty of Science, University of Tokyo, and Yasuo KASAHARA, formerly Professor of Okayama University, who led her to the field of spodography and SEM observation. Recent samples were provided by Professor Sadao SAKAMOTO of the Plant Germ Plasma Institute, Kyoto University, to whom the author expresses her gratefulness. For SEM operation the author received the technical assistance of Miss Masae Toyama and Miss Tomoko YAMASHITA and is thankful to them.

\section{Note}

Part of this study has already been reported in Japanese (MATSUTANI, 1986a).

\section{抄 録}

走査電子顕徽鏡による豊里遺跡出土炭化キビの識別

松谷暁子

古代から栽培されていた日本の主要雑穀三種である アワ, ヒエ, キビのうち, 遺跡からの出土報告が一番 少ないのがキビである，小粒であるイネ科雑穀は，炭
化物の場合, 走查型電子顕微鏡 (SEM) に上る微細構 造の観察によらないかぎり, 識別が困難なため, 最も 普遍的なアワとして三者が包活されている場合がある。 本報告では，アワとヒエの報告例（松谷 1986b, 1987） に続き, SEM によりキビ粒と判定された事例を示し た. 北海道天塩郡豊富町の豊里遺跡（擦文期）から出 土した炭化粒で従来アワと考兄られていたものである。

\section{References}

Hayashi, Z. 1969: Agricultural Customs in Ainu. (In Japanese)

[林 善茂, 1969: アイヌの農耕文化.]

KonNo, H. 1959: On the U-shaped large iron tool found in Hokkaido. Short Communication of Archaeological Society of Hokkaido Educational University No. 19, 89-91. (In Japanese) [河野広道, 1959: 北海道出土の大 U 型字形鉄器に ついて. 北海道学芸大学考古学研究会連絡紙 19 号, 89-91.]

Matsutani, A. 1980: On the identification of carbonized remains from the Tokachiputo Wakatsuki Site. Report of Urahoro Museum 16: 5-13. (In Japanese)

[松谷晆子, 1980：十勝太若月遺跡出土炭化物につ いて．浦幌町郷土博物館報告16号，5-18.]

MatsuTANi, A. 1986a: On the identification of carbonized seeds from the Toyotomi Site. Report of Asahikawa City Museum 16:1-11. (In Japanese)

[松谷暁子, 1986a：豊富町豊富遺跡出土種子の同定 について. 市立旭川郷土博物館研究報告16号 1-11.]

Matsutani, A. 1986b: Identification of Italian Millet from Esashika Site by Means of Scanning Electron Microscope. J. Anthrop. Soc. Nippon, 94-1, 111-118.

Matsutani, A. 1987: Identification of Japanese Millet from the Gangetsu Site by means of a Scanning Electron Microscope. J. Anthrop. Soc. Nippon, 95-2, 187-193.

Umemoto, K. and K. Hozumi, 1971: A pharmacognostical application of low-temperature ashing: microscopic observations on the mineral structure of "Dan-Zhu-ye" and its related species of Gramineae. Chem Pharm. Bull., 19, 217-219.

WATANABE N., 1970: A spodographic analysis of millets from prehistoric Japan. Jour. Fac. Sci. Univ. Tokyo, Sect. V, 357-379. 
松谷暁子東京大学総合研究資料館人類先史部門

T113 東京都文京区本郷 7-3-1

Akiko Matsutani Department of Anthropology and Prehistory, University of Tokyo 7-3-1 Hongo, Bunkyo-ku, Tokyo 113, Japan. 